\title{
PENGARUH MODEL PBI (PROBLEM BASED INSTRUCTIONS) DISERTAI MEDIA AUDIOVISUAL TERHADAP KETERAMPILAN PROSES SAINS DAN HASIL BELAJAR SISWA (Materi Momentum dan Impuls Kelas X MAN 1 Jember)
}

\author{
${ }^{1)}$ Ika Nur Aini Alfianti, ${ }^{1)}$ Singgih Bektiarso, ${ }^{1)}$ Albertus Djoko Lesmono \\ Program Studi Pendidikan Fisika FKIP Universitas Jember \\ ikanuraini14@gmail.com
}

\begin{abstract}
The purpose of this research were to study the effect of PBI (Problem Based Instructions) model with audiovisual media towards the student's science process skills and student learning outcomes. This research was an experiment research conducted in MAN 1 Jember. The population in this research were all students of $X^{\text {th }}$ grade in MIA MAN 1 Jember academic year 2016/2017. The data on student's science process skills and student learning outcomes were obtained from written tests at the end of momentum and impulse learning in the experiment class and control class. To examine the hypothesis, this research used independent sample t-test with SPSS 23 version. According to the independent sample t-test analysis, the results of this research were as follows: (1) PBI (Problem Based Instructions) model with audiovisual media has an significant effect to science process skill in physics $X^{\text {th }}$ grade in MAN 1 Jember and (2) PBI (Problem Based Instructions) model with audiovisual media has an significant effect to student learning outcomes in physics $X^{\text {th }}$ grade in MAN 1 Jember.
\end{abstract}

Keyword: PBI (problem based instructions), audiovisual media, student's science process skills, student learning outcomes.

\section{PENDAHULUAN}

Fisika adalah ilmu yang lahir dan berkembang melalui langkah-langkah observasi, perumusan masalah, penyusunan hipotesis, pengujian hipotesis melalui eksperimen, penarikan kesimpulan, serta penemuan teori dan konsep (Trianto, 2011:63). Dalam mencapai tujuan pembelajaran, khususnya fisika dalam proses pembelajaran harus mengaitkan materi dengan kehidupan nyata untuk diselidiki dan dipecahkan oleh siswa, hal tersebut sesuai dengan pembelajaran pada kurikulum 2013. Implementasi kurikulum 2013, mengharuskan dalam suatu pembelajaran tidak hanya mempelajari konsep, teori, dan fakta, tetapi juga aplikasi dalam kehidupan sehari-hari. Dengan demikian, materi pembelajaran tidak hanya tersusun atas halhal sederhana yang bersifat hafalan dan pemahaman, tetapi juga tersusun atas materi yang kompleks yang memerlukan analisis, aplikasi, dan sintesis (Trianto, 2014:11). Jadi, proses pembelajaran fisika berdasarkan kurikulum 2013, menekankan materi pada konteks nyata agar materi yang diterima oleh siswa lebih mudah dipahami.

Berdasarkan hasil observasi yang telah dilakukan di beberapa SMA di Kabupaten Jember menunjukkan bahwa hasil belajar siswa pada mata pelajaran fisika tergolong rendah. Hal ini dikarenakan hasil belajar siswa masih ada yang di bawah KKM. 
Pelajaran fisika dianggap pelajaran yang sulit dibandingkan dengan pelajaran lainnya. Hal ini disebabkan proses pembelajaran yang masih berpusat pada guru, sehingga siswa kurang aktif dalam pembelajaran. Materi yang disampaikan oleh guru sering menggunakan model pembelajaran langsung (direct instructions) dengan menggunakan metode ceramah, diskusi dan penugasan. Kegiatan pembelajaran dengan menggunakan metode ceramah cenderung membuat siswa pasif dalam pembelajaran. Oleh karena itu, agar pembelajaran dapat membuat siswa menjadi aktif perlu mengembangkan model pembelajaran yang sesuai dengan pembelajaran fisika. Model pembelajaran yang sesuai dengan pembelajaran fisika adalah yang melibatkan siswa untuk berperan aktif dan menyusun pengetahuannya sendiri.

Hasil belajar yang harus dinilai selain hasil belajar kognitif (pengetahuan) yaitu keterampilan proses sains siswa. Keterampilan proses sains yaitu seluruh keterampilan ilmiah yang dapat digunakan untuk menemukan konsep, prinsip, dan teori (Nurhudayah dkk., 2016:83). Menurut Widayanto (2009:2) menjelaskan keterampilan proses sains merupakan kemapuan atau kecakapan untuk melaksanakan suatu tindakan dalam belajar sains sehingga menemukan konsep, teori, prinsip, hukum dan fakta atau bukti. Sedangkan menurut (Hasanah dkk., 2016:135) menjelaskan keterampilan proses sains dapat memberikan kesempatan kepada siswa tidak hanya sekedar memperoleh pengetahuan saja, tetapi siswa juga menemukan pengetahuan secara mandiri.

Berdasarkan permasalahan tentang pembelajaran yang sering berpusat pada guru, maka diperlukan suatu penerapan pembelajaran yang sesuai dengan tujuan pembelajaran fisika. Salah satu model pembelajaran yang berpusat pada siswa dan mengaitkan pembelajaran dengan permasalah kehidupan sehari-hari yaitu model pembelajaran PBI (Problem Based Instructions). PBI (Problem Based Instructions) merupakan model pembelajaran yang melibatkan peserta didik untuk memecahkan suatu masalah melalui tahaptahap metode ilmiah (saintifik) sehingga peserta didik dapat mempelajari pengetahuan yang berhubungan dengan masalah tersebut dan sekaligus memiliki kemampuan untuk memecahkan masalah (Bektiarso, 2015:71). Menurut Fidayasari dkk. (2014:286) menjelaskan model PBI (Problem Based Instructions) merupakan suatu model pembelajaran yang menggunakan masalah dunia nyata untuk belajar sehingga siswa dilatih menyusun sendiri pengetahuannya, mengembangkan keterampilan pemecahan masalah, mandiri serta meningkatkan kepercayaan diri. Sedangkan menurut Ngabdiningsih dkk. (2013:8) menjelaskan model Problem Based Instructions memberikan kesempatan kepada siswa untuk terlibat secara aktif dan mengembangkan rasa ingin tahu siswa dilatih memecahkan suatu masalah nyata sehari-hari yang dekat dengan kehidupan siswa sehingga menghasilkan produk atau karya sendiri.

Model pembelajaran PBI (Problem Based Instructions) dalam penerapannya tentu memiliki kelemahan. Salah satu kelemahan dalam penerapan PBI yaitu sulit mengaitkan materi dengan permasalahan yang relevan. Oleh karena itu, maka diperlukan media pembelajaran untuk memunculkan permasalahan yaitu dengan menggunakan media audiovisual. Media audiovisual adalah kombinasi antara audio dan visual yang dikombinasikan dengan kaset audio yang mempunyai unsur suara dan gambar Purwono dkk. (2014:130). Sedangkan menurut Puspitasari dkk. (2015:213) menjelaskan bahwa media audiovisual merupakan gabungan media visual (gambar) dan media audio (suara) yang berperan dalam menyajikan fenomena- 
fenomena alam yang digunakan sebagai permasalahan dalam pembelajaran.

Model pembelajaran PBI (Problem Based Instruction) berbantuan media audiovisual merupakan pelaksanaan pembelajaran dengan menggunakan model pembelajaran PBI dengan memberikan motivasi penerapan pembelajaran dalam kehidupan sehari-hari, mengorientasikan siswa pada permasalahan sehari-hari, dan memberikan penguatan hasil pembelajaran yang disajikan melalui media audiovisual. Model pembelajaran PBI (Problem Based Instruction) berbantuan media audiovisual mendorong siswa untuk menganalisis masalah, mencari informasi, menyusun hipotesis, serta memecahkan masalah dengan bantuan media audiovisual.

Penelitian yang berkaitan dengan model PBI (Problem Based Instructions) adalah penelitian yang dilakukan oleh Dewi dkk. (2017:52) hasil penelitian menunjukkan bahwa rata-rata nilai post test kelas eksperimen lebih baik dari pada kelas kontrol. Azizah dkk. (2016:160) dalam penelitiannya menyatakan bahwa pembelajaran dengan menggunakan model Problem Based Instructions memberikan kesempatan kepada siswa untuk berperan aktif dalam proses pembelajaran sehingga hasil belajar siswa pada kelas eksperimen lebih baik dari pada kelas kontrol. Penelitian yang berkaitan dengan media audiovisual adalah penelitian yang dilakukan oleh Purwono dkk. (2014:142) hasil penelitian menunjukkan hasil belajar mengalami peningkatan setelah guru menggunakan media audiovisal di SMP Negeri 1 Pacitan. Peningkatan hasil belajar juga diikuti oleh peningkatan daya serap siswa dalam menerima pelajaran.

Tujuan penelitian ini yaitu: (1) mengkaji pengaruh model PBI (Problem Based Instructions) disertai media audiovisual terhadap keterampilan proses sains siswa dan (2) mengkaji pengaruh model PBI (Problem Based Instructions) disertai media audiovisual terhadap hasil belajar siswa.

\section{METODE}

Penelitian ini dilakukan dengan cara memberikan perlakuan berupa pembelajaran dengan menggunakan model PBI (Problem Based Instructions) disertai media audiovisual pada kelas eksperimen, sedangkan pada kelas kontrol tidak mengguanakan model PBI (Problem Based Instructions) disertai media audiovisual. Jenis penelitian yang dilakukan adalah penelitian eksperimen. Penelitian ini dilakukan di MAN 1 Jember pada semester genap tahun ajaran 2016/2017.

Subyek populasi dalam penelitian ini adalah seluruh siswa kelas X MIA MAN 1 Jember yang terdiri dari 5 kelas (X MIA 1, X MIA 2, X MIA 3, X MIA 4 dan X MIA 5). Sebelum menentukan sampel, dilakukan uji homogenitas dengan Anova (Analisis of Variance) terhadap populasi dengan menggunakan program SPSS versi 23. Uji homogenitas dilakukan dengan maksud untuk menguji kesamaan awal siswa. Berdasarkan hasil uji homogenitas One Way Anova, didapatkan nilai signifikansi sebesar 0,174 . Nilai signifikansi tersebut lebih besar dari taraf nyata $(0,05)$ atau dapat dituliskan $0,174>0,05$, yang berarati kelas X MIA MAN 1 Jember memiliki varians yang homogen. Selanjutnya, dilakukan cluster random samplimg untuk menentukan sampel penelitian. Adapun kelas yang digunakan sebagai kelas eksperimen yaitu X-MIA 2 dan kelas kontrol yaitu X-MIA 3. Desian penelitian yang digunakan pada penelitian ini adalah adalah post-test only control group design.

Metode pengumpulan data dalam penelitian ini yaitu dilakukan dengan tes, dokumentasi dan wawancara. Data keterampilan proses sains dan hasil belajar 
siswa dalam penelitian ini diperoleh dengan menggunakan tes tulis pada akhir pertemuan materi momentum dan impuls pada kelas eksperimen dan kelas kontrol. Indikator keterampilan proses sains yang diukur terdiri dari keterampilan proses sains dasar dan terintegrasi, sedangkan indikator hasil belajar yang diukur adalah hasil belajar kognitif terdiri dari klasifikasi $\mathrm{C}_{1}$ sampai $\mathrm{C}_{6}$. Dokumetasi dilakukan untuk memperoleh data nama siswa, nilai ulangan sebelumnya dan foto kegiatan pembelajaran saat penelitian. Sedangkan wawancara dilakukan sebelum dan setelah penelitian dilakukan kepada guru fisika dan siswa kelas X.

Teknik analisis data keterampilan proses sains dan hasil belajar siswa dengan menggunakan Independent Sample T Test berbantuan software SPSS versi 23 dengan uji pihak kanan pada taraf signifikan $5 \%$ apabila data terdistribusi normal. Sedangkan apabila data tidak terdistribusi normal menggunakan Nonparametrik Test- 2 Samples Independent Test dengan uji pihak kanan pada taraf signifikan $5 \%$.

Hipotesis nol dalam penelitian ini berbunyi nilai rata-rata keterampilan proses sains siswa kelas eksperimen tidak berbeda dengan kelas kontrol dan nilai rata-rata hasil belajar siswa pada kelas eksperimen tidak berbeda dengan kelas kontrol. Sedangkan bunyi hipotesis alternatifnya yaitu nilai ratarata keterampilan proses sains siswa kelas eksperimen lebih baik dari kelas kontrol dan nilai rata-rata hasil belajar siswa pada kelas eksperimen lebih baik dari kelas kontrol. Kriteria uji $t$ test yaitu sebagai berikut:

a. Sig ( $p$ value) $>0,05$ maka hipotesis nihil $\left(\mathrm{H}_{0}\right)$ diterima dan hipotesis alternatif $\left(\mathrm{H}_{\mathrm{a}}\right)$ ditolak.

b. Sig ( $p$ value) $\leq 0,05$ maka hipotesis nihil $\left(\mathrm{H}_{0}\right)$ ditolak dan hipotesis alternatif $\left(\mathrm{H}_{\mathrm{a}}\right)$ diterima.

\section{HASIL DAN PEMBAHASAN}

Data keterampilan proses sains siswa diperoleh dari hasil tes tulis setelah akhir pertemuan materi momentum dan impuls pada kelas eksperimen dan kontrol. Berikut rekapitulasi keterampilan proses sains siswa pada kelas eksperimen dan kelas kontrol yang ditunjukkan pada Tabel 1 .

Tabel 1. Rekapitulasi Keterampilan Proses Sains Siswa

\begin{tabular}{lcc}
\hline \multicolumn{1}{c}{ Aspek keterampilan proses sains } & \multicolumn{2}{c}{ Kelas } \\
\cline { 2 - 3 } & Eksperimen & Kontrol \\
\hline Mendefinisikan variabel secara operasional & $84,00 \%$ & $76,00 \%$ \\
\hline Mengidentifikasi variabel & $65,50 \%$ & $33,00 \%$ \\
\hline Menggambarkan hubungan antar variabel & $77,00 \%$ & $62,00 \%$ \\
\hline Memprediksi & $81,00 \%$ & $72,00 \%$ \\
\hline Menyusun hipotesis & $74,00 \%$ & $58,00 \%$ \\
\hline Membuat tabulasi data & $98,00 \%$ & $84,00 \%$ \\
\hline Menyajikan data dalam bentuk grafik & $67,00 \%$ & $69,00 \%$ \\
\hline Mengobservasi & $98,00 \%$ & $70,00 \%$ \\
\hline Mengklasifikasikan & $71,00 \%$ & $56,00 \%$ \\
\hline Menyimpulkan & $64,00 \%$ & $30,00 \%$ \\
\hline Mengumpulkan dan mengolah data & $65,50 \%$ & $47,00 \%$ \\
\hline Menganalisis penelitian & $53,00 \%$ & $33,00 \%$ \\
\hline Mengkomunikasikan & $42,00 \%$ & $10,00 \%$ \\
\hline Merancang penelitian & $81,00 \%$ & $59,00 \%$ \\
\hline Mengukur & $62,00 \%$ & $45,00 \%$ \\
\hline Melaksanakan eksperimen & $58,00 \%$ & $27,00 \%$ \\
\hline
\end{tabular}




\begin{tabular}{ccc}
\hline Aspek keterampilan proses sains & \multicolumn{2}{c}{ Kelas } \\
\cline { 2 - 3 } & Eksperimen & Kontrol \\
\hline Jumlah & $\mathbf{1 1 4 1 , 0 0 \%}$ & $\mathbf{8 3 1 , 0 0 \%}$ \\
\hline Rata-rata & $\mathbf{7 1 , 3 1 \%}$ & $\mathbf{5 1 , 9 3 \%}$ \\
\hline
\end{tabular}

Berdasarkan Tabel 1, dapat diketahui bahwa skor keterampilan proses sains pada kelas eksperimen lebih tinggi dari pada kelas kontrol. Hal tersebut dikarenakan pada kelas eksperimen dalam setiap pembelajaran menerapkan model PBI (Problem Based Instructions) disertai media audiovisual sehingga siswa dilatih keterampilan proses sainsnya. Dalam setiap pembelajaran siswa diberi LKS yang isinya telah disesuaikan dengan sintakmatik model PBI (Problem Based Instructions) disertai media audiovisual. Pada kegiatan awal siswa melakukan pengamatan penerapan pembelajaran dalam kehidupan sehari-hari dan permasalahan pembelajaran melalui media audiovisual. Setelah melakukan pengamatan, siswa memiliki gambaran awal dan dapat menyusun hipotesis dari kegiatan pembelajaran. Selanjutnya, siswa melakukan percobaan untuk memecahkan permasalahan yang terdapat pada media audiovisual sehingga siswa dapat menemukan konsep sendiri. Kemudian pada kegiatan akhir pembelajaran, siswa menyimpulkan hasil pembelajaran dan guru memberikan penguatan melalui media audiovisual. Sedangkan pada kelas kontrol kegiatan pembelajaran tidak menggunakan model PBI (Problem Based Instructions) disertai media audiovisual sehingga siswa tidak dilatih keterampilan proses sainsnya.

Data keterampilan proses sains yang didapatkan kemudian dianalisis dengan mengguankan uji t dengan bantuan versi 23 . Sebelum dilakukan uji t, terlebih dahulu dilakukan uji normalitas keterampilan proses sains siswa dan didapatkan nilai Sig. (2tailed) pada kelas kontrol dan kelas eksperimen yaitu 0,200 . Nilai tersebut lebih besar dari 0,05 atau dapat ditulis 0,200 > 0,05 , sehingga dapat disimpulkan bahwa data nilai keterampilan proses sains siswa pada kelas eksperimen dan kelas kontrol terdistribusi normal. Selanjutnya karena data terditribusi normal, maka uji t dilakukan dengan menggunakan uji statistik parametrik yaitu uji Independent sample T-Test. Setelah dilakukan uji $t$ dengan menggunakan Independent Sample T Test diperoleh nilai Sig. (2-tailed) sebesar 0,000. Pengujian hipotesis yang digunakan dalam penelitian ini adalah pengujian hipotesis pihak kanan, sehingga nilai signifikansi (2-tailed) dibagi 2 dan diperoleh signifikansi (1-tailed) sebesar 0,000. Nilai Signifikansi tersebut kurang dari 0,05 maka $\mathrm{H}_{\mathrm{a}}$ diterima dan $\mathrm{H}_{0}$ ditolak, artinya keterampilan proses sains siswa kelas eksperimen lebih baik dari kelas kontrol sehingga dapat disimpulkan bahwa ada pengaruh model PBI (Problem Based Instruxtions) disertai media audiovisual terhadap keterampilan proses sains siswa kelas X MAN 1 Jember.

Hasil penelitian ini sesuai dengan beberapa penelitian yang telah dilakukan sebelumnya, yaitu penelitian yang dilakukan oleh Amelia dkk. (2014:8) bahwa dengan menerapkan model PBI mendapatkan respon positif dari siswa, hal tersebut dapat dilihat dari keterampilan proses sains yang meningkat setelah penerapan model PBI dalam proses pembelajaran. Siswa memiliki kesempatan untuk terlibat aktif melakukan percobaan bersama kelompoknya, melakukan pengamatan dari percobaan yang dilakukan, membuat tabel data hasil pengamatan percobaan, berdiskusi dengan kelompok untuk menjawab masalah berupa pertanyaan dan menyampaikan hasil percobaan dan diskusi di depan kelas.

Data kedua yang diperoleh dalam penelitian ini yaitu hasil belajar siswa. Hasil belajar siswa yang dikaji adalah hasil belajar kompetensi kognitif (pengetahuan). Berikut rekapitulasi hasil belajar siswa pada kelas 
eksperimen dan kelas kontrol ditunjukkan pada Tabel 2.

Tabel 2. Rekapitulasi Hasil Belajar Siswa

\begin{tabular}{ccc}
\hline & Eksperimen & Kontrol \\
\hline Jumlah Siswa & 30 & 36 \\
\hline Nilai Tertinggi & 100,00 & 87,50 \\
\hline Nilai Terendah & 50,00 & 25,00 \\
\hline Nilai Rata-rata & 74,58 & 65,27 \\
\hline Standar Deviasi & 12,08 & 17,95 \\
\hline $\begin{array}{c}\text { Siswa yang } \\
\text { tuntas }\end{array}$ & $\begin{array}{c}22 \text { org } \\
(70,96 \%)\end{array}$ & $\begin{array}{c}14 \text { org } \\
(38,89 \%)\end{array}$ \\
\hline
\end{tabular}

Berdasarkan Tabel 2, dapat diketahui bahwa rata-rata hasil belajar siswa pada kelas eksperimen lebih tinggi dari pada kelas kontrol. Hasil belajar siswa pada kelas eksperimen yang lebih tinggi itu menunjukkan bahwa dengan adanya pengamatan siswa pada penerapan pembelajaran dalam kehidupan sehari-hari dan permasalahan pembelajaran melalui media audiovisual kemudian dilanjutkan dengan kegiatan siswa melakukan percoban untuk memecahkan permasalahan yang terdapat pada media audiovisual sehingga siswa dapat menemukan konsep sendiri dapat melatih kreativitas siswa dalam menyelesaikan suatu masalah sehingga dapat melatih kemampuan pengetahuan siswa.

Data hasil belajar siswa yang didapatkan kemudian dianalisis dengan mengguankan uji t dengan bantuan versi 23 . Sebelum dilakukan uji t, terlebih dahulu dilakukan uji normalitas hasil belajar siswa dan diperoleh nilai Sig. (2-tailed) pada kelas eksperimen yaitu 0,000 dan pada kelas kontrol yaitu 0,001 . Nilai tersebut $<0,005$, sehingga dapat disimpulkan bahwa data nilai hasil belajar siswa pada kelas eksperimen dan kelas kontrol tidak terdistribusi normal. Selanjutnya, karena data tidak terdistribusi normal, maka uji $\mathrm{t}$ dilakukan dengan menggunakan uji statistik non parametrik yaitu dengan menggunakan Uji 2 Independent Sample T-Test.

Setelah dilakukan uji 2 Independent Sample T-Test didapatkan nilai Sig. (2 tailed) sebesar 0,041 atau dapat ditulis 0,041 $<0,05$. Maka dapat disimpulkan bahwa nilai rata-rata hasil belajar siswa kelas ekperimen lebih baik dari kelas kontrol. Sehingga ada pengaruh model PBI (Problem Based Instructions) disertai media audiovisual terhadap hasil belajar siswa kelas X MAN 1 Jember. Selanjutnya, Sig. (2-tailed) dibagi 2 sehingga didapatkan Sig. (1-tailed) sebesar 0,0205 sehingga dapat dituliskan $0,0205<$ 0,05 . Maka dapat disimpulkan bahwa nilai rata-rata hasil belajar siswa kelas ekperimen lebih baik dari kelas kontrol. Sehingga ada pengaruh model PBI (Problem Based Instructions) disertai media audiovisual terhadap hasil belajar siswa kelas X MAN 1 Jember.

Hal ini sesuai dengan penelitian Dewi dkk. (2017:52) menunjukkan bahwa hasil belajar fisika siswa pada kelas eksperimen lebih baik dibandingkan dengan kelas kontrol. Sehingga dapat disimpulkan bahwa hasil belajar fisika siswa menggunakan model PBI disertai metode demonstrasi lebih baik dibandingkan dengan menggunakan model pembelajaran yang biasa digunakan di sekolah. Penelitian lain yang dilakukan oleh Azizah dkk. (2016:160) dalam penelitiannya menyatakan bahwa pembelajaran dengan menggunakan model Problem Based Instructions memberikan kesempatan kepada siswa untuk berperan aktif dalam proses pembelajaran. Tahapantahapan Problem Based Instruction menampilkan bagian dari urutan proses yang membantu siswa dari pengalamannya sendiri sehingga hasil belajar siswa pada kelas eksperimen lebih baik dari pada kelas kontrol. 
Terlaksananya proses pembelajaran menggunakan model PBI (Problem Based Instructions) disertai media audiovisual tidak terlepas dari kendala yang ada, diantaranya yaitu: (1) sulitnya pembuatan media audiovisual yang sesuai dengan materi pembelajaran, (2) sulit dalam pembuatan alat dan bahan percobaan momentum dan impuls yang sesuai dan valid sehingga dibutuhkan berulang kali percobaan dan membutuhkan dana yang cukup sehingga ketersediannya terbatas dan (3) keterbatasan waktu yang ada sehingga membuat pembalajaran begitu singkat. Apabila kendala-kendala tersebut dapat diminimalisir maka tidak menutup kemungkinan tujuan pembelajaran dapat tercapai dengan maksimal.

\section{SIMPULAN DAN SARAN}

Berdasarkan hasil analisis yang diperoleh, maka dapat disimpulkan sebagai berikut: (1) model PBI (Problem Based Instructions) disertai media audiovisual berpengaruh signifikan terhadap keterampilan proses sains siswa dalam pembelajaran fisika kelas X MAN 1 Jember dan (2) model PBI (Problem Based Instructions) disertai media audiovisual berpengaruh signifikan terhadap hasil belajar siswa dalam pembelajaran fisika kelas $\mathrm{X}$ MAN 1 Jember.

Berdasarkan hasil penelitian dan pembahasan, maka saran yang dapat diberikan antara lain: (1) bagi guru, pembelajaran menggunakan model PBI (Problem Based Instructions) disertai media audiovisual dapat dijadikan alternatif untuk diterapkan dalam pembelajaran fisika di kelas. Dalam pelaksanaannya, guru harus menyiapkan pembelajaran secara matang seperti pembuatan media audiovisual yang sesuai dengan materi pembelajaran dan dibuat semenarik mungkin sehingga dapat memotivasi siswa untuk belajar dan (2) bagi peneliti lain, penelitian ini dapat dijadikan sebagai masukan bagi peneliti lain untuk penelitian lebih lanjut dengan pokok bahasan yang berbeda serta dapat mengembangkan media audiovisual yang lebih baik lagi sehingga dapat menyempurnakan dan menutupi kekurangan model ini.

\section{DAFTAR PUSTAKA}

Amelia, A., Hartono, dan D. K. Sari. 2014. Penerapan Model Problem Based Instructions (PBI) untuk Meningkatkan Keterampilan Proses Sains di Sekolah Menengah Atas. Jurnal Pendidikan Kimia. Vol. 1(1): 1-8.

Azizah, N., Subiki, dan R. D. Handayani. 2016. Penerapan Model Problem Based Inruction terhadap Kemampuan Berpikir Kritis dan Hasil Belajar Siswa dalam Pembelajaran Fisika di SMA. Jurnal Pembelajaran Fisika. Vol. 5(2): 156-161.

Bektiarso, S. 2015. Strategi Pembelajaran. Yogyakarta: LaksBang PRESSindo.

Dewi, D. A. D. R., S. Bektiarso, dan Subiki. 2017. Pengaruh Model Pembelajaran Problem Based Instruction disertai Metode Pictorial Riddle terhadap Hasil Belajar dan Kemampuan Berpikir Kritis Siswa pada Mata Pelajaran Fisika di SMA. Jurnal Pembelajaran Fisika. Vol. 6(1): 4855.

Fidayasari, S., Sudarti, dan Subiki. 2014. Model Pembelajaran Problem Based Instruction (PBI) disertai Teknik Probing-Prompting dalam Upaya Meningkatkan Kemandirian dan Hasil Belajar Fisika di Kelas X 2 MAN 1 
Jember. Jurnal Pendidikan Fisika. Vol. 3(3): 285-293.

Hasanah, H., I. K. Mahardika, dan B. Supriadi. 2016. Penerapan Model Pembelajaran Inkuiri disertai LKS Berbasis Multirepresentasi terhadap Keterampilan Proses Sains dan Hasil Belajar Siswa dalam Pembelajaran Fisika di SMAN Kabupaten Jember. Jurnal Pembelajaran Fisika. Vol. 5(2): 135-140.

Ngabdiningsih, S. W., E. Susantini, dan Ismono. 2013. Penerapan Model Pembelajaran Problem Based Instruction (PBI) Pendekatan science, Environment, Technology, and Society (SETS) untuk Meningkatkan Hasil Belajar Siswa pada Tema Banjir. Jurnal Pendidikan Sains. Vol. 1(2):714.

Nurhudayah, M., A. D. Lesmono, dan Subiki. 2016. Penerapan Model Inkuiri Terbimbing (Guided Inquiry) dalam Pembelajaran Fisika SMA di Jember (Studi pada Keterampilan Proses Sains dan Keterampilan Berpikir Kritis). Jurnal Pembelajaran Fisika. Vol. 5(1): 82-88.
Purwono, J., S. Yutmini, dan S. Anitah. 2014. Penggunaan Media AudioVisual pada Mata Pelajaran Ilmu Pengetahuan Alam di Sekolah Menengah Pertama Negeri 1 Pacitan. Jurnal teknologi Pendidikan dan Pembelajaran.Vol. 2(2): 127-144.

Puspitasari, R., A. D. Lesmono, dan T. Prihandono. 2015. Pengaruh Model Pembelajaran POE (Prediction, Observation and Explanation) disertai Media Audiovisual terhadap Keterampilan Kerja Ilmiah dan Hasil Belajar Siswa dalam Pembelajaran IPA-Fisika di SMP. Jurnal Pembelajaran Fisika. Vol. 4(3): 211218.

Trianto. 2011. Model Pembelajaran Terpadu. Jakarta: Bumi Aksara.

Trianto. 2014. Mendesain Model Pembelajaran Inovatif, Progresif, dan Kontekstual. Jakarta: Prenadamadia Group.

Widayanto. 2009. Pengembangan Keterampilan Proses dan Pemahaman Siswa kelas X Melalui Kit Optik. Jurnal Pendidikan Fisika Indonesia. Vol. 5(1). 1-7. 